\title{
An amphiphilic organic catalyst for the direct asymmetric Michael addition of cycloketone to nitroolefins in water
}

\author{
Jianwei Wei ${ }^{a, b}$, Wengang Guo ${ }^{b}$, Boyu Zhang ${ }^{b}$, Yan Liu ${ }^{b, *}$, Xin Du ${ }^{a, \#, ~ C a n ~ L i ~ b, \$ ~}$ \\ a Department of Chemistry, Dalian University of Technology, Dalian 116024, Liaoning, China \\ b State Key Laboratory of Catalysis, Dalian Institute of Chemical Physics, Chinese Academy of Sciences, Dalian 116023, Liaoning, China
}

\section{A R T I C L E I N F}

\section{Article history:}

Received 21 December 2013

Accepted 11 March 2014

Published 20 July 2014

Keywords:

Asymmetric catalysis

Emulsion

Organocatalysis

Michael addition

\begin{abstract}
A B S T R A C T
A series of amphiphilic proline-derived mercapto imidazole organic catalysts were synthesized and shown to be very effective with an acid cocatalyst for the asymmetric Michael addition reaction of ketones to nitroolefins with high diastereoselectivity (up to 99:1) and execellent enantioselectivity (up to $96 \%$ ) using water as solvent.
\end{abstract}

(c) 2014, Dalian Institute of Chemical Physics, Chinese Academy of Sciences. Published by Elsevier B.V. All rights reserved.
Water is environmentally benign, safe and cheap compared to organic solvents, and therefore the use of water as the reaction solvent has received much attention in the field of green chemistry. However, the incompatibility between organic reactants and water limits its applications.

The Michael addition is one of the most powerful methods for the formation of $\mathrm{C}-\mathrm{C}$ bonds in organic synthesis [1]. Since List et al. [2] reported the proline-catalyzed asymmetric Michael addition reaction, the direct asymmetric Michael addition of unmodified carbonyl compounds into nitro olefins has been regarded as an efficient synthesis route for chiral $\gamma$-nitro carbonyl compounds [3-7], which serve as versatile building blocks for the synthesis of complex organic molecules $[8,9]$. Meanwhile, effective organocatalytic Michael addition reactions in an aqueous system have also been reported by several research groups [10-12]. In 2006, Barbas III's group developed a catalytic direct asymmetric Michael reaction of ketones to nitroolefins that can be performed in brine using an amphiphilic protonated diamine organic catalyst [10]. In the same year, Luo et al. [11] synthesized surfactant-type organic catalysts (SAT0) for the same reactions in water. In case, high enantioselectivity up to $98 \%$ and diastereoselectivity up to $99 \%$ were observed. Recently, Syu et al. [12] reported a new second amine catalyst bearing a sulfide which showed high catalytic activity toward the direct asymmetric Michael reaction of cyclohexanone and aromatic nitroolefins using water as the solvent. In the above cases, reactions involving aliphatic nitroolefins were not reported [13-15]. Therefore, the development of a new method for asymmetric Michael addition to aliphatic nitroolefins using water as solvent is in demand.

Recently, the development of amphiphilic organic catalysts that form an emulsion system has proved to be a promising

\footnotetext{
* Corresponding author. Tel: +86-411-84379302; Fax: +86-411-84694447; E-mail: yanliu503@dicp.ac.cn

\# Corresponding author. E-mail: duxin@dlut.edu.cn

\$ Corresponding author. Tel: +86-411-84379070; Fax: +86-411-84694447; E-mail: canli@dicp.ac.cn

This work was supported by the National Natural Science Foundation of China (21002100) and the Fundamental Research Funds for the Central Universities of China (DUT12LK07).

DOI: 10.1016/S1872-2067(14)60080-2 | http://www.sciencedirect.com/science/journal/18722067 | Chin. J. Catal., Vol. 35, No. 7, July 2014
} 


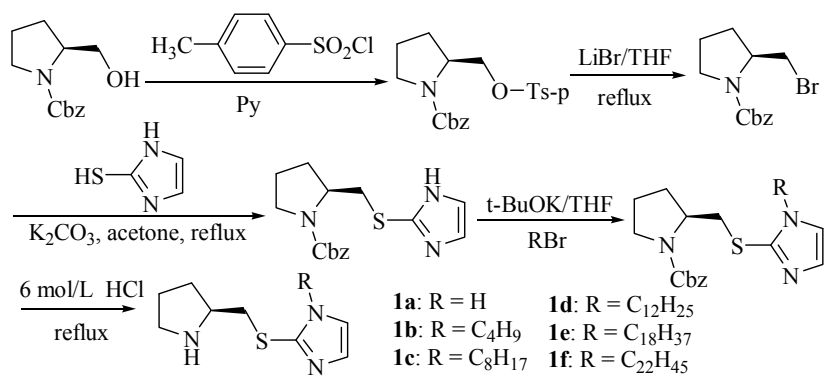

Scheme 1. Synthesis of the catalysts.

strategy to improve mass diffusion limitation in water-oil biphasic organocatalytic systems [16-19]. As our continuing effort to develop new chiral emulsion organocatalytic systems, we envisioned that the strategy of emulsion catalysis would increase the reactivity of aliphatic nitroolefins in the aqueous Michael addition reaction because of the increased frequency of contact between the catalyst, that has a long carbon chain, and the substrates. In this communication, we report a new amphiphilic proline-derived mercapto imidazole organic catalyst, which forms an emulsion system in the reaction mixture by self-assembly.

A series of proline-based organic catalysts bearing a mercapto imidazole motif (Scheme 1) with different hydrophobic alkyl chains were designed and synthesized in five steps from commercially available N-Cbz-L-prolinol. The details for the synthesis of the catalysts were given in the Supporting Information.

The model asymmetric Michael reaction of cyclohexanone 2a to $\beta$-trans-nitroolefin $\mathbf{3 a}$ was conducted in water by using $20 \mathrm{~mol} \%$ catalyst loading at room temperature. The results are given in Table 1 . All the catalysts promoted this reaction (Table 1, entries 1-6), especially catalysts $\mathbf{1 d - 1 f}$ bearing hydrophobic

Table 1

Catalysts screened for the reaction of cyclohexanone $\mathbf{2 a}$ and nitroolefin 3a. ${ }^{\text {a }}$

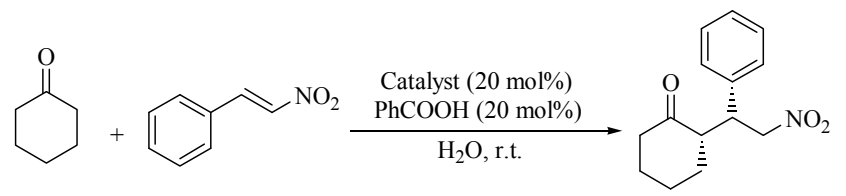

\begin{tabular}{lccc} 
2a & 3a & & 4a \\
\hline Entry & Catalyst & Conversion $^{\mathrm{b}}(\%)$ & $\mathrm{ee}^{\mathrm{c}}(\%)$ \\
\hline 1 & 1a & 61 & 91 \\
2 & $\mathbf{1 b}$ & 62 & 93 \\
3 & $\mathbf{1 c}$ & 69 & 92 \\
4 & $\mathbf{1 d}$ & 85 & 92 \\
5 & $\mathbf{1 e}$ & 97 & 84 \\
6 & $\mathbf{1 f}$ & 75 & 91 \\
$7^{\mathrm{d}}$ & $\mathbf{1 d}$ & 94 & 87 \\
$8^{\mathrm{e}}$ & $\mathbf{1 d}$ & 99 & 83 \\
$9^{\mathrm{f}}$ & $\mathbf{1 d}$ & 99 & 87 \\
\hline
\end{tabular}

a Unless otherwise noted, all reactions were carried out at room temperature in water $(0.5 \mathrm{~mL})$, catalyst $1(20 \mathrm{~mol} \%)$, benzoic acid $(20$ mol\%), 2a (1.2 mmol), 3a ( $0.20 \mathrm{mmol})$, reaction time $5 \mathrm{~h}$.

${ }^{\mathrm{b}}$ Determined by ${ }^{1} \mathrm{H}$ NMR.

'Determined by chiral HPLC analysis.

d $0.5 \mathrm{~mL} \mathrm{CH}_{2} \mathrm{Cl}_{2}$ was used.

e $0.5 \mathrm{~mL} \mathrm{CHCl}_{3}$ was used.

${ }^{\mathrm{f}}$ The reaction was carried out in neat condition.

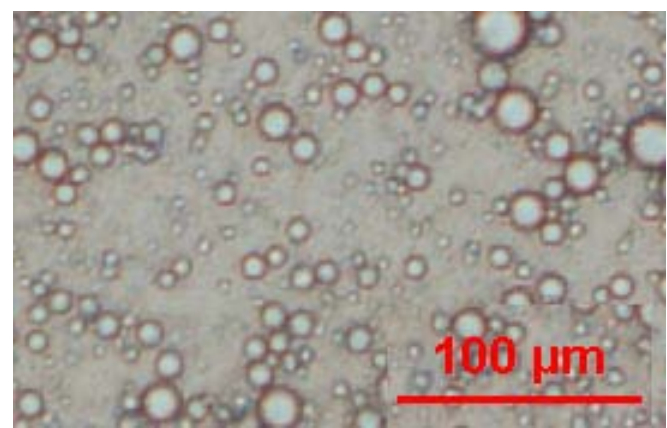

Fig. 1. Microscope images of the emulsion system formed with $\mathbf{1 d}$.

alkyl chains with different lengths, which exhibited higher activities in metastable emulsion states (Fig. 1). Catalyst 1d with a dodecane moiety was the most efficient. The reaction also proceeded efficiently in an organic solvent or under neat condition. However, small decreases in enantioselectivity were observed (Table 1, entries 7-9).

An extensive study of various acids other than benzoic acid highlighted the importance of the nature of the acidic counterpart. As illustrated in Table 2, the activity varied dramatically with the different acids. Only $63 \%$ yield after $72 \mathrm{~h}$ was achieved when no additive was added (Table 2, entry 9). In the presence of the strong acid $\mathrm{CF}_{3} \mathrm{COOH}$, only a trace of the desired product was detected (Table 2, entry 7). The reactions with the relatively weak acids such as aliphatic and aromatic acids as the additive gave products in higher yield (up to $99 \%$ yield, Table 2 , entries $1-6,8)$. On the basis of both the reactivity and enantioselectivity, 4-nitrobenzoic acid was chosen.

Under the optimal reaction conditions, a variety of nitrostyrenes bearing different substitutions were investigated. The results are summarized in Table 3. Various styrene-type nitroalkenes reacted smoothly with cyclohexanone to provide the corresponding adducts in good yield with high enantioselectiv-

Table 2

Influence of the additive on the reaction of cyclohexanone $\mathbf{2 a}$ and nitroolefin $3 \mathbf{a}^{\text {a }}$

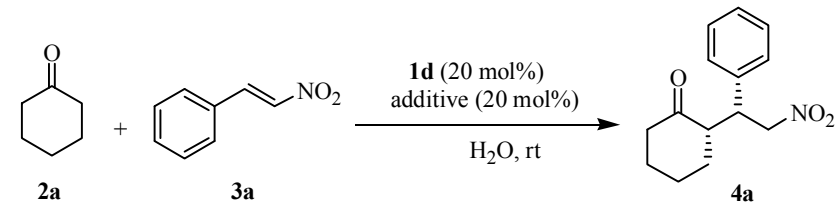

\begin{tabular}{lcccc} 
2a & 3a & & & 4a \\
\hline Entry & Additive & Time $(\mathrm{h})$ & Yield $^{\mathrm{b}}(\%)$ & ee $^{\mathrm{c}}(\%)$ \\
\hline 1 & benzoic acid & 12 & 83 & 92 \\
2 & 4-methylbenzoic acid & 12 & 87 & 93 \\
3 & 4-methoxybenzoic acid & 12 & 89 & 93 \\
4 & 4-hydroxybenzoic acid & 12 & 90 & 92 \\
5 & 4-nitrobenzoic acid & 12 & 99 & 93 \\
6 & Salicylic acid & 12 & 99 & 92 \\
7 & $\mathrm{CF}_{3} \mathrm{COOH}$ & 12 & 16 & 92 \\
8 & $\mathrm{CH}_{3} \mathrm{CH}_{2} \mathrm{COOH}$ & 12 & 81 & 93 \\
9 & - & 72 & 63 & 90 \\
\hline
\end{tabular}

a Unless otherwise noted, all reactions were carried out at room temperature in water $(0.5 \mathrm{ml})$, catalyst $1 \mathbf{d}(20 \mathrm{~mol} \%)$, benzoic acid (20 mol\%), 2a (1.2 mmol), 3a (0.20 mmol).

$\mathrm{b}$ Isolated yield based on $3 \mathrm{a}$.

c Determined by chiral HPLC analysis. The absolutely configuration was determined to be $(S, S)$ by comparing with the $[\alpha]_{D}^{25}$ in the literature.

d No additive was added. 
Table 3

Michael addition of ketones $\mathbf{2}$ to nitroolefins 3.

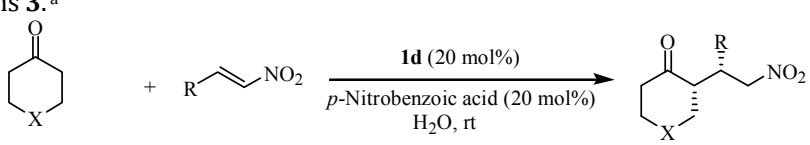

\begin{tabular}{|c|c|c|c|c|c|c|c|c|c|c|c|}
\hline & & & 2a X $=\mathrm{CH}_{2} ; \mathbf{2 l}$ & $=0$ & & & & & & & \\
\hline Entry & Product & $\begin{array}{l}\text { Time } \\
\text { (h) }\end{array}$ & $\begin{array}{c}\text { Yield }^{\mathrm{b}} \\
(\%)\end{array}$ & $\begin{array}{c}\text { d.r. }{ }^{c} \\
\text { (syn:anti) }\end{array}$ & $\begin{array}{l}e^{c} \\
(\%)\end{array}$ & Entry & Product & $\begin{array}{c}\text { Time } \\
\text { (h) }\end{array}$ & $\begin{array}{c}\text { Yield }^{\mathrm{b}} \\
(\%)\end{array}$ & $\begin{array}{c}\text { d.r. }{ }^{c} \\
\text { (syn:anti) }\end{array}$ & $\begin{array}{l}\mathrm{ee}^{\mathrm{c}} \\
(\%)\end{array}$ \\
\hline 1 & & 12 & 99 & $99: 1$ & 93 & 7 & & 72 & 71 & $87: 13$ & 90 \\
\hline 2 & & 24 & 73 & $97: 3$ & 94 & 8 & & 96 & 87 & 99:1 & 86 \\
\hline 3 & & 36 & 84 & $96: 4$ & 92 & 9 & & 96 & 70 & $99: 1$ & 94 \\
\hline 4 & & 8 & 69 & 99:1 & 94 & 10 & & 50 & 61 & 99:1 & 91 \\
\hline 5 & & 60 & 92 & $95: 5$ & 96 & 11 & & 72 & 70 & 99:1 & 90 \\
\hline 6 & & 24 & 76 & $95: 5$ & 95 & & & & & & \\
\hline
\end{tabular}

${ }^{a}$ All reactions were carried out at room temperature in water (0.5 ml), $\mathbf{1 d}(20 \mathrm{~mol} \%)$, benzoic acid (20 mol\%), $2 \mathrm{a}(1.2 \mathrm{mmol}), 3 \mathbf{3}(0.20 \mathrm{mmol})$.

b Isolated yield based on $\mathbf{3 a}$.

c Determined by chiral HPLC analysis.

ity (Table 3, entries 1-6). The electronic nature of the substituents on the benzene ring of nitroolefin 3 influenced slightly the enantioselectivity (90\%-95\% ee) and activity. Nitroolefin containing thiophenyl was also a suitable substrate as a Michael acceptor (Table 3, entry 7). In addition, the cyclohexanone derivative $\mathbf{2} \mathbf{b}$ proved to be an available donor in this catalytic system (Table 3, entry 8). Noticeably, aliphatic substituted nitroolefins were also good candidates for this asymmetric Michael addition reaction although they showed slightly lower reactivity than the $\beta$-aryl-nitroolefins (Table 3, entries 9-11).

Cyclopentanone was also investigated as a donor in the 1d-catalyzed Michael addition with 3a (Scheme 2). The reaction proceeded smoothly and showed moderate diastereoselectivity and good enantioselectivity.

In summary, we have designed and synthesized a class of novel amphiphilic organic catalysts which were successfully

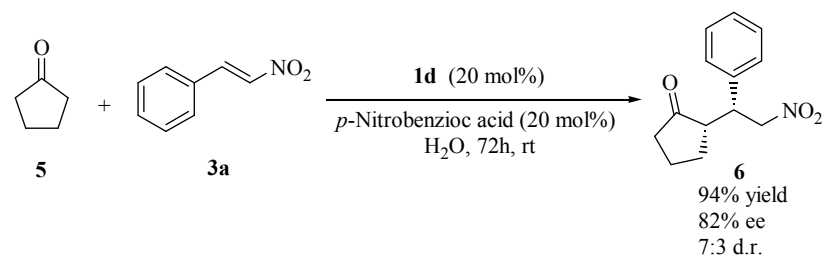

Scheme 2. Michael addition of $\mathbf{5}$ with $\mathbf{3 a}$. used in the asymmetric Michael addition of cyclohexanone with nitroolefins in water. The emulsion state was crucial for achieving high activity and enantioselectivity.

\section{References}

[1] Perlmutter P. Conjugate Addition Reactions in Organic Synthesis. Pergamon: Oxford, 1992

[2] List B, Pojarliev P, Martin H J. Org Lett, 2001, 3: 2423

[3] Alexakis A, Andrey O. Org Lett, 2002, 4: 3611

[4] Luo S Z, Xu H, Mi X, Li J, Zheng X, Cheng J P. J Org Chem, 2006, 71: 9244

[5] Mo L, Tang H, Yao Z. Tetrahedron, 2013, 33: 6897

[6] Zhao H, Li H, Yue Y, Sheng Z. Eur J Org Chem, 2013, 2013: 1740

[7] Zhong J, Guan Z, He Y. Catal Commun, 2013, 32: 18

[8] Lu A, Gao P, Wu Y, Wang Y, Zhou Z, Tang C. Org Biomo Chem, 2009, 7: 3141

[9] Czekelius C, Carreira E M. Angew Chem Int Ed, 2005, 44: 612

[10] Mase N, Watanabe K, Yoda H, Takabe K, Tanaka F, Barbas III C F. J Am Chem Soc, 2006, 128: 4966

[11] Luo S Z, Mi X, Liu S, Cheng J P. Chem Commun, 2006, 35: 3687

[12] Syu S, Kao T, Lin W. Tetrahedron, 2010, 66: 891

[13] Wang J J, Lao J H, Du D S, Nie S Z, Hu Z P, Yan M. Chirality, 2012, 24: 232

[14] Chuan Y M, Chen G H, Peng Y G. Tetrahedron Lett, 2009, 50: 3054

[15] Ibrahem I, Cordova A. Tetrahedron Lett, 2005, 46: 3363 


\title{
Graphical Abstract
}

Chin. J. Catal., 2014, 35: 1008-1011 doi: 10.1016/S1872-2067(14)60080-2

An amphiphilic organic catalyst for the direct asymmetric Michael addition of cycloketone to nitroolefins in water

Jianwei Wei, Wengang Guo, Boyu Zhang, Yan Liu*, Xin Du*, Can Li*

Dalian University of Technology; Dalian Institute of Chemical Physics, Chinese Academy of Sciences

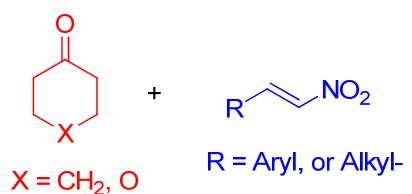

$$
\mathrm{X}=\mathrm{CH}_{2}, \mathrm{O}
$$
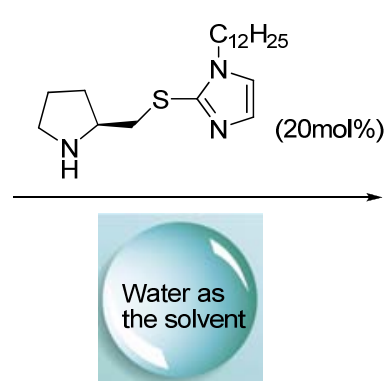

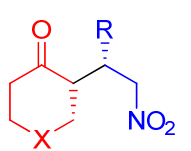

up to $99 \%$ yield 99: $1 \mathrm{dr}$

Michael addition was catalyzed by a new amphiphilic proline-derived mercapto imidazole organic catalyst using water as solvent with high diastereoselectivity (99:1 d.r.) and execellent enantioselectivity (96\% ee).

[16] Zhong L, Gao Q, Gao J, Xiao J, Li C. J Catal, 2007, 250: 360

[17] Mase N, Noshiro N, Mokuya A, Takabe K. Adv Synth Catal, 2009, 351: 2791
[18] Gao Q, Liu Y, Lu S M, Li J, Li C. Green Chem, 2011, 13: 1983

[19] Zhang B Y, Jiang Z X, Zhou X, Lu S M, Li J, Liu Y, Li C. Angew Chem Int Ed, 2012, 51: 13159

\section{一种新型双亲性有机小分子催化剂在水相体系中催化环己酮与硝基烯烃 直接不对称Michael加成反应}

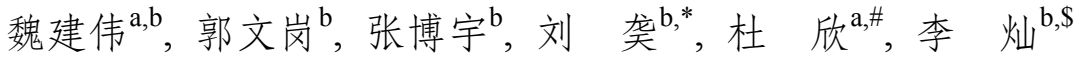 \\ a大连理工大学化工学院, 辽宁大连 110624 \\ ${ }^{\mathrm{b}}$ 中国科学院大连化学物理研究所催化基础国家重点实验室, 辽宁大连 110623
}

摘要: 设计合成了一系列基于脯氨酸巯基咪唑衍生物的新型双亲性有机小分子催化剂, 在水相中加入酸作为助催化剂, 可以高效 高选择性的催化环己酮与硝基烯烃的不对称Michael加成反应, 非对映选择性和对映选择性分别高达 $99: 1$ 和 $96 \%$.

关键词: 不对称催化; 乳液; 有机催化; 迈克尔加成

收稿日期: 2013-12-21. 接受日期: 2014-03-11. 出版日期: 2014-07-20.

*通讯联系人. 电话: (0411)84379302; 传真: (0411)84694447; 电子信箱: yanliu503@dicp.ac.cn

通讯联系人. 电子信箱: duxin@dlut.edu.cn

\$通讯联系人. 电话: (0411)84379070; 传真: (0411)846944477; 电子信箱: canli@dicp.ac.cn

基金来源：国家自然科学基金(21002100); 中央高校基础研究基金(DUT12LK07).

本文的英文电子版由Elsevier出版社在ScienceDirect上出版(http://www.sciencedirect.com/science/journal/18722067). 